\title{
Effect of drying condition on physicochemical and antioxidant properties of dried Moringa leaf powder
}

\author{
1,*Razzak, A., ${ }^{2}$ Roy, K.R., ${ }^{3}$ Sadia, U., ${ }^{2}$ Mominul, H., ${ }^{2}$ Suvro, T., ${ }^{2}$ Sikder, M.B.H. and \\ ${ }^{2}$ Zzaman, W. \\ ${ }^{1}$ Bangladesh Institute of Research and Training on Applied Nutrition, Regional Office, Sunamganj, Sylhet, \\ Bangladesh \\ ${ }^{2}$ Department of Food Engineering and Tea Technology, Shahjalal University of Science and Technology, \\ Sylhet 3114, Bangladesh \\ ${ }^{3}$ Department of Botany, Dhaka University, Dhaka, Bangladesh
}

\section{Article history:}

Received: 21 December 2020

Received in revised form: 9

February 2021

Accepted: 16 May 2021

Available Online: 12

December 2021

\section{Keywords:}

Moringa leaves,

Drying temperature,

Antioxidant activity,

Physicochemical analysis

DOI:

https://doi.org/10.26656/fr.2017.5(6).759

\section{Introduction}

Moringa oleifera is residential principally in India, Bangladesh, Afghanistan, Pakistan, Brazil, Southeast Asia, West Asia, Sri Lanka, East and West Africa, Southern Florida, West Indies, and from Mexico to Peru and Paraguay (Chaudhary and Chaurasia, 2017). Moringa oleifera Lam. tree flourishes in numerous tropical and subtropical regions. Moringa oleifera tree has a place with the group of Moringaceae. In some countries, Moringa is called a "drumstick tree" or horseradish tree and is privately called "zogale" in Hausa, Nigeria. It is familiar for its multipurpose qualities (Bashir et al., 2016). Moringa oleifera is familiar with its excellent quality such as fast-growing even in impoverished soil, drought tolerant, deciduous tree (Ferreira et al., 2008). It develops excellent in hot, semi-dry, and moist regions and the suitable soil is sandy or loamy soils. The seed must be moderately new to give decent germination. Warm temperatures are significant for germination. Someone called Moringa "Miracle Tree" or "Mother's best friend" also for its high nutritional quality (Daba, 2016). Moringa has multipurpose use like medicinal uses, industrial uses, nutritional uses, economic uses, which can be used for water conservation and green manure also (Daba, 2016). Moringa plant has importance for human beings because almost all parts of Moringa (seed, pods, flower, and leaf) are edible (Daba, 2016). Moringa leaves are exceptionally perishable and require processing to protect against losses during postharvest. The best way of preserving Moringa leaves is drying. After the drying 
process, dry leaves require to convert into leaf powder and store (Emelike and Ebere, 2016; Affandi et al., 2017).

Traditionally, Moringa oleifera is utilized to treat numerous maladies all around the world and a large number of them are experimentally demonstrated, which for the most part incorporate, antiasthmatic, antihypertensive, antibiotic, antiulcer, CNS-depressant, anthelmintic, anti-inflammatory (Isitua et al., 2015). In many developing countries, many people cannot get the opportunity of medical services, they suffer from many kinds of diseases. Therapeutic plants offer possible cures with huge chances (Kumbhare et al., 2012). As a medicinal plant, Moringa is a blessing for many countries, especially those who are suffering from poor health conditions and poverty. For the water purification method, the watery extract of kernels of Moringa is used (Makkar and Becker, 1997).

Moringa is wealthy in numerous nutrients. It has more than 90 nutrient components. It has many antioxidant components and all eight vital amino acids with good proportions (Offor et al., 2014). The leaves of Moringa have high nutritional components. It contains vitamin $\mathrm{C}, \beta$-carotene, protein, minerals such as iron, potassium, and calcium, also. Moringa has flavonoid components that help to prevent diseases such as heart diseases and give protection against chronic degenerative diseases (Coppin et al., 2013). The iron substance of the leaves is high and they are recommended for iron deficiency and are utilized in the treatment of scurvy skin maladies (Abbas et al., 2018). During pregnancy, if a woman takes 6 teaspoons of dried Moringa leaves powder regularly they can meet iron and calcium demand (Gopalakrishnan et al., 2016). Moringa oleifera leaves are additionally great resources of phytonutrients, for example, tocopherols and carotenoids. These supplements are known to scavenge free radicals at the point when joined with a reasonable eating regimen and may have immunosuppressive impacts (Oyeyinka and Oyeyinka, 2018). Moringa oleifera leaves act as an antidiabetic agent (Gopalakrishnan et al., 2016). Moringa leaves have Vitamin A content more than carrots, Vitamin $\mathrm{C}$ content more than oranges, calcium more than milk, potassium more than bananas, and iron more than spinach (Fahey, 2005). The moisture content of a product plays a pivotal role in determining the shelf life of the product. Drying can reduce the moisture content of Moringa leaf but it also causes different nutrient losses. Thus, an optimum temperature is needed for drying to minimize the nutritional loss and moisture content (Olabode et al., 2015). The present study aimed to evaluate the impact of drying conditions on the physicochemical and antioxidant properties of dried
Moringa leaves powder.

\section{Materials and methods}

\subsection{Sample handling and preparation}

Fresh Moringa leaves were collected from the Sunamganj district of Bangladesh. The stalk and branches of the leaves were removed followed by washing with distilled water. Then the leaves were dried in an oven dryer at different temperatures: $60^{\circ} \mathrm{C}, 70^{\circ} \mathrm{C}$ and $80^{\circ} \mathrm{C}$ for $2 \mathrm{hrs}$. The dried Moringa leaves were then ground into powder form and sieved in a 100 mesh to obtain fine particles. The powder found from Moringa leaves dried at different drying temperatures was stored in a different airtight vessel.

\subsection{Moisture content determination}

The moisture content of the dried Moringa leaf powder was determined according to a method described by (Rajput et al., 2017; Moazzem et al., 2019). Firstly, the powder was taken into a crucible and weighed $\left(\mathrm{W}_{1}\right)$. Then it was dried at $105^{\circ} \mathrm{C}$ for $24 \mathrm{hrs}$ in an oven drier and weighed again $\left(\mathrm{W}_{2}\right)$. The moisture content of the sample was calculated according to the following equation:

$$
\text { Moisture content }=\left(\left(\mathrm{W}_{1}-\mathrm{W}_{2}\right) / \mathrm{W}_{1} \times 100\right.
$$

\subsection{Ash content determination}

A method described by (Akubugwo et al., 2007) was followed to determine the ash content of the dried Moringa leaf powder. Approximately $3 \mathrm{~g}$ of Moringa leaf powder was taken into a crucible. The sample was then heated at $550^{\circ} \mathrm{C}$ for $8 \mathrm{hrs}$ in a muffle furnace and residue was determined.

\subsection{Fat content determination}

The fat content of the dried Moringa leaf powder was determined according to a method described by (Ravichandran and Parthiban, 2000). Firstly, $5 \mathrm{~g}$ of dried Moringa leaf powder was mixed with $25 \mathrm{~mL}$ methanol and chloroform mixture $(2: 1)$ in a separating funnel. Then $5 \mathrm{~mL}$ of $0.9 \%$ sodium chloride was added. Three layers were seen in the separating funnel. The lowest layer was collected in a pre-weighed beaker and heated at $80^{\circ} \mathrm{C}$ in a water bath. The residue amount was then measured.

\subsection{Protein content determination}

According to the Kjeldahl method described by (Offor et al., 2014) protein content of the dried Moringa leaf powder was estimated. Firstly, the digestion of the powder was done with a digestion mixture and sulfuric acid. After digestion, the distillation of the digested sample was carried out in a distillation chamber. The 
titrate value was then measured by $\mathrm{HCl}$. The percentage of nitrogen content was found by this method. To determine the protein content, nitrogen percentage was multiplied by a conversion factor.

\subsection{Carbohydrate content determination}

Carbohydrate content was estimated according to Phenol sulfuric acid method described by (Agrawal et al., 2015). Firstly, $0.1 \mathrm{~g}$ dried Moringa leaf powder was boiled in a water bath for $3 \mathrm{hrs}$. The sample was then neutralized by adding solid sodium carbonate. The volume of the sample was made $100 \mathrm{~mL}$ by adding distilled water and centrifuging. The supernatant was used as the sample for further process. $0.2 \mathrm{~mL}$ sample was made $1 \mathrm{~mL}$ by adding distilled water. After that, 1 $\mathrm{mL}$ of $5 \%$ phenol and $5 \mathrm{~mL}$ of $96 \%$ sulfuric acid were incorporated into the sample and the absorbance of the sample was taken at $490 \mathrm{~nm}$ wavelength by spectrophotometer. The percentage of carbohydrate content was determined by using Glucose standard curve.

\subsection{Optical properties}

The optical properties of dried Moringa leaf powder were evaluated by a colorimeter. A standard plate $\left(L^{*}\right.$ : 89.87, $a^{*}: 2.52$ and $b^{*}:$-3.36) was used to measure the $L^{*}, a^{*}$ and $b^{*}$ values of the dried Moringa leaf powder (Zzaman et al., 2014).

\subsection{Total phenol content}

Total phenol content was determined according to a method described by (Amorim et al., 2008; Shin et al., 2015). At first extract, the solution was prepared by adding $80 \%$ methanol to $0.5 \mathrm{~g}$ dried Moringa leaf powder. Then, $0.5 \mathrm{~mL}$ extract was mixed with $8.5 \mathrm{~mL}$ distilled water and $0.5 \mathrm{~mL}$ Folin-Ciocalteu and kept for a few minutes. $1 \mathrm{~mL}$ of $35 \%$ sodium carbonate solution was then added to the mixture and absorbance was taken at $765 \mathrm{~nm}$ wavelength. Total phenol content was determined by the Gallic acid standard curve.

\subsection{Determination of DPPH free radical scavenging activity}

DPPH free radical scavenging activity was determined according to the method described by Chang et al. (2001). At first extract, the solution was prepared. Then, $2 \mathrm{~mL}$ extract sample incorporated into $2 \mathrm{~mL}$ DPPH $(0.16 \mathrm{mM})$ methanol solution and kept in dark condition. The absorbance of the mixture was measured at $517 \mathrm{~nm}$ wavelength by spectrophotometer.

\subsection{Determination of vitamin C content}

According to a method described by (Ranganna,
1986), vitamin $\mathrm{C}$ content was determined. At first $5 \mathrm{~mL}$ standard ascorbic acid and $5 \mathrm{~mL}$ Meta phosphoric acid was taken into a conical flask. The dye solution was put into a burette for titration of the sample. Dye factor was obtained by this process. Then titration of the $5 \mathrm{~g}$ sample was done by adding $3 \%$ of $\mathrm{HPO}_{3}$.

\subsection{Determination of $\beta$-carotene}

$\beta$-Carotene content was determined by using a method described by (Biswas et al., 2011; Hossain et al., 2021). Approximately $5 \mathrm{~g}$ of chilled acetone and $1 \mathrm{~g}$ of sample was taken in a test tube. The mixture was then centrifuged and the supernatant was taken into another test tube. After making the standard $\beta$-Carotene content absorbance of extract and standard $\beta$-Carotene solution was taken at $421 \mathrm{~nm}$ wavelength by spectrophotometer.

\subsection{Statistical analysis}

The SAS software (version 9.4, SAS Institute Inc., Cary, NC, USA) was used with one-way analysis of variance (ANOVA). Duncan multiple range tests $(\mathrm{p}<$ 0.05 ) was performed to statistically analyze the mean values. All experiments were repeated at least 3 times and the data were represented as mean \pm standard deviation.

\section{Results and discussion}

\subsection{Physicochemical properties of dried Moringa leaf powder}

The moisture content of the Moringa leaf powder dried at $60^{\circ} \mathrm{C}$ samples, $70^{\circ} \mathrm{C}$ samples and $80^{\circ} \mathrm{C}$ samples were found $4.96 \%, 2.89 \%$ and $2.57 \%$ respectively (Table 1). Different drying temperature affects the moisture content of dried Moringa leaf powder. (Alakali et al., 2015) reported that increasing drying temperature reduces the moisture content of Moringa leaves. According to Sanni et al. (2006) sample containing lower moisture content has a longer shelf life. Singh and Prasad (2013) reported that unblanched Moringa leaf dried at $60^{\circ} \mathrm{C}$ contain $5.67 \%$ moisture content. Rajput et al. (2017) showed fresh and dried Moringa leaves contain $72.83 \%$ and $7.43 \%$ moisture content respectively.

Ash content for the sample dried at $60^{\circ} \mathrm{C}, 70^{\circ} \mathrm{C}$ and $80^{\circ} \mathrm{C}$ were found $10.3 \%, 9.81 \%$ and $9.39 \%$ respectively. A significant decrease in ash content was found with increasing drying temperature. Oluduro (2012) reported similar results and found $10.64 \%$ ash content in dried Moringa leaf powder. According to Alakali et al. (2015), the ash content of Moringa leaf powder dried at $60^{\circ} \mathrm{C}$ and $70^{\circ} \mathrm{C}$ were $5.22 \%$ and $5.20 \%$ respectively which illustrates a similar decrease in ash content with 
Table 1. Moisture, ash, fat, protein and carbohydrate content of Moringa leaf powder.

\begin{tabular}{cccccc}
\hline Drying Temperature & Moisture & Ash & Fat & Protein & Carbohydrate \\
\hline $60^{\circ} \mathrm{C}$ & $4.96 \pm 0.16^{\mathrm{b}}$ & $10.30 \pm 0.44^{\mathrm{c}}$ & $4.96 \pm 0.16^{\mathrm{a}}$ & $24.67 \pm 0.03^{\mathrm{c}}$ & $45.57 \pm 0.30^{\mathrm{c}}$ \\
$70^{\circ} \mathrm{C}$ & $2.89 \pm 0.09^{\mathrm{a}}$ & $9.81 \pm 0.70^{\mathrm{b}}$ & $5.19 \pm 0.13^{\mathrm{b}}$ & $21.65 \pm 0.02^{\mathrm{b}}$ & $43.40 \pm 0.14^{\mathrm{b}}$ \\
$80^{\circ} \mathrm{C}$ & $2.57 \pm 0.08^{\mathrm{a}}$ & $9.39 \pm 0.02^{\mathrm{a}}$ & $5.33 \pm 0.25^{\mathrm{c}}$ & $19.89 \pm 0.03^{\mathrm{a}}$ & $41.57 \pm 0.03^{\mathrm{a}}$ \\
\hline
\end{tabular}

Values are presented as mean $\pm \mathrm{SD}, \mathrm{n}=5$. Values with different superscripts within the same column are significantly different ( $\mathrm{p}$ $<0.05)$ by Duncan's multiple range tests.

increasing drying temperature.

Fat content for the Moringa leaf powder dried at $60^{\circ}$ C, $70^{\circ} \mathrm{C}$ and $80^{\circ} \mathrm{C}$ were found $4.96 \%, 5.19 \%$ and $5.33 \%$ respectively. The change in fat content is significant but very small which may be due to inherent variation of the composition of natural products. Ilyas et al. (2015) found $2.89 \%$ of fat content in dried Moringa leaf. A similar result for fat content was reported by Sengev et al. (2013).

A significant difference was found for the protein content of Moringa leaf powder dried at different temperatures. Moringa leaf dried at $60^{\circ} \mathrm{C}, 70^{\circ} \mathrm{C}$ and $80^{\circ}$ $\mathrm{C}$ contained $24.67 \%, 21.65 \%$ and $19.89 \%$ protein respectively. The significant decrease in protein content of the Moringa leaf powder with increasing drying temperature was due to increased protein denaturalization (Alakali et al., 2015). The protein content of Moringa leaf powder dried at $60^{\circ} \mathrm{C}$ and $70^{\circ} \mathrm{C}$ were found $20.75 \%$ and $19.89 \%$ respectively (Alakali et al., 2015). Chinwe et al. (2015) reported that dried Moringa leaf powder contains $24.31 \%$ protein.

The carbohydrate content of Moringa leaf powder dried at $60^{\circ} \mathrm{C}, 70^{\circ} \mathrm{C}$ and $80^{\circ} \mathrm{C}$ were found $45.57 \%$, $43.4 \%$, and $41.57 \%$ respectively. Carbohydrate content decreased with increasing drying temperature. A decrease in carbohydrate content may be the result of the thermal degradation of carbohydrates during drying (Lemus-Mondaca et al., 2016). Oluduro (2012) found $45.43 \%$ carbohydrate in dried Moringa leaf powder which is similar to this study.

\subsection{Optical properties}

From Table 2, the $L^{*}$ value of the powder increased continuously from 42.38 to 43.24 with the increased drying temperature of Moringa leaf powder. A significant increase in lightness is indicated by the increase in the $L^{*}$ value of the powder. The $b^{*}$ value of the powder decreased from 32.63 to 28.24 with the increase of drying temperature which indicates a decrease in yellowness of the Moringa leaf powder. The increase in lightness and decrease in yellowness of the dried powder may be due to the breakdown of chlorophyll with increasing drying temperature (Sejali and Anuar, 2011).

\subsection{Antioxidant properties of dried Moringa leaf powder}

Total phenol content of the sample dried at $60^{\circ} \mathrm{C}$ samples, $70^{\circ} \mathrm{C}$ samples and $80^{\circ} \mathrm{C}$ samples are found $38.30 \mathrm{mg} / 110 \mathrm{~g}, 27.77 \mathrm{mg} / 100 \mathrm{~g}$ and $16.39 \mathrm{mg} / 100 \mathrm{~g}$ respectively (Table 3 ). Total phenol content decreased with the increasing drying temperature of the dried Moringa leaf powder. Potisate and Phoungchandang (2015) reported that reduction in drying time helps to retain higher total phenol content.

DPPH free radical scavenging activity of the dried Moringa leaves powder decreased from $77.79 \%$ to $56.42 \%$ with the increase in drying temperature from $60^{\circ}$ $\mathrm{C}$ to $80^{\circ} \mathrm{C}$. Moringa leaf powder dried at $70^{\circ} \mathrm{C}$ possessed $63.30 \%$ DPPH free radical scavenging activity. Ilyas et

Table 2. Optical properties of dried Moringa leaf powder

\begin{tabular}{cccccc}
\hline Drying Temperature & $L^{*}$ & $a^{*}$ & $b^{*}$ & $c^{*}$ & $d^{*}$ \\
\hline $60^{\circ} \mathrm{C}$ & $42.38 \pm 0.17^{\mathrm{b}}$ & $3.16 \pm 0.02^{\mathrm{a}}$ & $32.63 \pm 0.10^{\mathrm{c}}$ & $32.44 \pm 0.35^{\mathrm{c}}$ & $95.54 \pm 0.03^{\mathrm{c}}$ \\
$70^{\circ} \mathrm{C}$ & $43.24 \pm 0.57^{\mathrm{b}}$ & $0.60 \pm 0.68^{\mathrm{b}}$ & $29.54 \pm 0.76^{\mathrm{b}}$ & $28.34 \pm 0.36^{\mathrm{b}}$ & $88.86 \pm 1.44^{\mathrm{b}}$ \\
$80^{\circ} \mathrm{C}$ & $46.00 \pm 1.70^{\mathrm{c}}$ & $2.33 \pm 0.20^{\mathrm{c}}$ & $28.24 \pm 0.71^{\mathrm{c}}$ & $28.34 \pm 0.76^{\mathrm{b}}$ & $84.61 \pm 0.89^{\mathrm{a}}$ \\
\hline
\end{tabular}

Values are presented as mean $\pm \mathrm{SD}, \mathrm{n}=5$. Values with different superscripts within the same column are significantly different ( $\mathrm{p}$ $<0.05)$ by Duncan's multiple range tests.

Table 3. Antioxidant properties of dried Moringa leaf powder

\begin{tabular}{ccccc}
\hline Drying Temperature & $\begin{array}{c}\text { Total phenol content } \\
(\mathrm{mg} / 100 \mathrm{~g})\end{array}$ & $\begin{array}{c}\text { Vitamin C content } \\
(\mathrm{mg} / 100 \mathrm{~g})\end{array}$ & $\begin{array}{c}\beta \text {-carotene content } \\
(\mathrm{mg} / 100 \mathrm{~g})\end{array}$ & DPPH (\%) \\
\hline $60^{\circ} \mathrm{C}$ & $38.30 \pm 0.77^{\mathrm{c}}$ & $21.45 \pm 0.12^{\mathrm{b}}$ & $22.71 \pm 0.03^{\mathrm{c}}$ & $56.42 \pm 0.38^{\mathrm{a}}$ \\
$70^{\circ} \mathrm{C}$ & $27.77 \pm 0.19^{\mathrm{b}}$ & $17.81 \pm 0.14^{\mathrm{a}}$ & $21.14 \pm 0.60^{\mathrm{b}}$ & $63.30 \pm 0.08^{\mathrm{b}}$ \\
$80^{\circ} \mathrm{C}$ & $16.39 \pm 0.40^{\mathrm{a}}$ & $17.00 \pm 0.04^{\mathrm{a}}$ & $19.87 \pm 0.06^{\mathrm{a}}$ & $77.79 \pm 0.12^{\mathrm{c}}$ \\
\hline
\end{tabular}

Values are presented as mean $\pm \mathrm{SD}, \mathrm{n}=5$. Values with different superscripts within the same column are significantly different ( $\mathrm{p}$ $<0.05)$ by Duncan's multiple range tests. 
al. (2015) found $87.02 \%$ DPPH free radical scavenging activity for dried Moringa leaf powder.

Vitamin $\mathrm{C}$ content for the sample dried at $60^{\circ} \mathrm{C}$ samples, $70^{\circ} \mathrm{C}$ samples and $80^{\circ} \mathrm{C}$ samples were found $21.45 \mathrm{mg} / 100 \mathrm{~g}, 17.81 \mathrm{mg} / 100 \mathrm{~g}$ and $17 \mathrm{mg} / 100 \mathrm{~g}$ respectively. Vitamin $\mathrm{C}$ is heat sensitive and thus reduced with increasing drying temperature (Igwemmar et al., 2013). $19.3 \mathrm{mg}$ of vitamin $\mathrm{C}$ content per $100 \mathrm{~g}$ of dried Moringa leaf powder was collected from Nigeria (Mensah et al., 2012)

Beta-carotene content of the Moringa leaf powder dried at $60^{\circ} \mathrm{C}, 70^{\circ} \mathrm{C}$ and $80^{\circ} \mathrm{C}$ were found $21.45 \mathrm{mg} / 100$ $\mathrm{g}, 17.81 \mathrm{mg} / 100 \mathrm{~g}$ and $17 . \mathrm{mg} / 100 \mathrm{~g}$ respectively. $\beta$ carotene content decreased with increasing drying temperature of Moringa leaf. Subadra et al. (1997) found $17.4 \mathrm{mg}$ of $\beta$-carotene content per $100 \mathrm{~g}$ of fresh Moringa leaves and found that $\beta$-carotene reduces after drying.

\section{Conclusion}

From this study, the drying temperature affects the nutrient component of Moringa leaves. And from this, the sample dried at $60^{\circ} \mathrm{C}$ temperature has higher amount of antioxidant and physicochemical content than another sample. And with the increasing of temperature, the loss of nutrient component occurs at most. Thus, the temperature of the sample in oven drying should maintain not more than $60^{\circ} \mathrm{C}$ temperature to get desirable product. Further studies needed to be carried out to analyse the stability of developed product from dried Moringa leaves and how many grams of dried powder should be given to pregnant women as an alternative to iron tablet.

\section{References}

Abbas, R., Elsharbasy, F. and Fadlelmula, A. (2018). Nutritional Values of Moringa oleifera, Total Protein, Amino Acid, Vitamins, Minerals, Carbohydrates, Total Fat and Crude Fiber, under the Semi-Arid Conditions of Sudan. Journal of Microbial Biochemical Technology, 10(2), 56-58. https://doi.org/10.4172/1948-5948.1000396

Affandi, N., Zzaman, W., Yang, T.A. and Easa, A.M. (2017). Production of Nigella sativa Beverage Powder under Foam Mat Drying Using Egg Albumen as a Foaming Agent. Beverages, 3(1), 9. https://doi.org/10.3390/beverages3010009

Agrawal, N., Minj, D. and Rani, K. (2015). Estimation of total carbohydrate present in dry fruits. Journal of Environmental Science, Toxicology and Food Technology, 1(6), 24-27.
Akubugwo, I., Obasi, A. and Ginika, S. (2007). Nutritional potential of the leaves and seeds of black nightshade-Solanum nigrum L. Var virginicum from Afikpo-Nigeria. Pakistan Journal of Nutrition, 6(4), 323-326. https://doi.org/10.3923/ pjn. 2007.323 .326

Alakali, J., Kucha, C. and Rabiu, I. (2015). Effect of drying temperature on the nutritional quality of Moringa oleifera leaves. African Journal of Food Science, 9(7), 395-399. https://doi.org/10.5897/ AJFS2014.1145

Amorim, E.L., Nascimento, J.E., Monteiro, J.M., Peixoto Sobrinho, T., Araújo, T.A. and Albuquerque, U.P. (2008). A simple and accurate procedure for the determination of tannin and flavonoid levels and some applications in ethnobotany and ethnopharmacology. Functional Ecosystems and Communities, 2(1), 88-94.

Bashir, K., Waziri, A. and Musa, D. (2016). Moringa oleifera, a potential miracle tree: a review. Journal of Pharmaceutical and Biological Science, 11(6), 2530.

Biswas, A., Sahoo, J. and Chatli, M. (2011). A simple UV-Vis spectrophotometric method for determination of $\beta$-carotene content in raw carrot, sweet potato and supplemented chicken meat nuggets. LWT-Food Science and Technology, 44(8), 1809-1813. https://doi.org/10.1016/j.lwt.2011.03.017

Chang, S.T., Wu, J.H., Wang, S.Y., Kang, P.L., Yang, N.S. and Shyur, L.F. (2001). Antioxidant activity of extracts from Acacia confusa bark and heartwood. Journal of Agricultural and Food Chemistry, 49(7), 3420-3424. https://doi.org/10.1021/jf0100907

Chaudhary, K. and Chaurasia, S. (2017). Nutraceutical properties of Moringa oleifera: a review. European Journal of Pharmaceutical and Medical Research, 4 (4), 646-655.https://doi.org/10.1007/s13596-02000468-0

Coppin, J.P., Xu, Y., Chen, H., Pan, M.H., Ho, C.T., Juliani, R., Simon, J.E. and. Wu, Q. (2013). Determination of flavonoids by LC/MS and antiinflammatory activity in Moringa oleifera. Journal of Functional Foods, 5(4), 1892-1899. https:// doi.org/10.1016/j.jff.2013.09.010

Daba, M.H. (2016). Miracle tree: A review on multipurposes of Moringa oleifera and its implication for climate change mitigation. Journal of Earth Science and Climate Change, 7(8). https://doi:10.4172/21577617.1000366

Emelike, N.and Ebere, C. (2016). Effect of Drying Techniques of Moringa Leaf on the Quality of ChinChin Enriched with Moringa Leaf Powder. Journal 
of Environmental Science, Toxicology and Food Technology, 10(4), 65-70. https://doi: 10.9790/24021004016570

Fahey, J.W. (2005). Moringa oleifera: A review of the medical evidence for its nutritional, therapeutic, and prophylactic properties. Part 1. Trees for life Journal, 1(5), 21205-22185.

Ferreira, P.M.P., Farias, D.F., Oliveira, J.T.D.A. and Carvalho, A.D.F.U. (2008). Moringa oleifera: bioactive compounds and nutritional potential. Revista de Nutrição, 21(4), 431-437. https:// doi.org/10.3390/antiox6040091

Gopalakrishnan, L., Doriya, K. and Kumar, D.S. (2016). Moringa oleifera: A review on nutritive importance and its medicinal application. Food Science and Human Wellness, 5(2), 49-56. https:// doi.org/10.1016/j.fshw.2016.04.001

Hossain, M.A., Mitra, S., Belal, M. and Zzaman, W. (2021). Effect of foaming agent concentration and drying temperature on biochemical properties of foam mat dried tomato powder. Food Research, 5 (1), 291 - 297.https://doi.org/10.26656/fr.2017.5 (1). 372

Igwemmar, N., Kolawole, S. and Imran, I. (2013). Effect of heating on vitamin $\mathrm{C}$ content of some selected vegetables. International Journal of Scientific and Technology Research, 2(11), 209-212.

Ilyas, M., Arshad, M., Saeed, F. and Iqbal, M. (2015). Antioxidant potential and nutritional comparison of Moringa leaf and seed powders and their tea infusions. Journal of Animal and Plant Sciences, 25 (1), 226-233.

Isitua, C.C., Lozano, M., Jaramillo, C. and Dutan, F. (2015). Phytochemical and nutritional properties of dried leaf powder of Moringa oleifera Lam. from Machala El Oro province of Ecuador. Asian Journal Plant Science Research, 5(2), 8-16.

Kumbhare, M., Guleha, V. and Sivakumar, T. (2012). Estimation of total phenolic content, cytotoxicity and in-vitro antioxidant activity of stem bark of Moringa oleifera. Asian Pacific Journal of Tropical Disease, 2(2), 144-150. https://doi.org/10.1016/S2222-1808 (12)60033-4

Makkar, H. and Becker, K. (1997). Nutrients and antiquality factors in different morphological parts of the Moringa oleifera tree. The Journal of Agricultural Science, 128(3), 311-322. https://doi.org/10.1017/ S0021859697004292

Mensah, J., Ikhajiagbe, B., Edema, N. and Emokhor, J. (2012). Phytochemical, nutritional and antibacterial properties of dried leaf powder of Moringa oleifera (Lam.) from Edo Central Province. Journal of
Natural Products and Plant Resources, 2(1), 107112.

Moazzem, M.S., Sikder, M.B.H. and Zzaman, W. (2019). Shelf-Life Extension of Wood Apple Beverages Maintaining Consumption-Safe Parameters and Sensory Qualities. Beverages, 5, 25. https://doi.org/10.3390/beverages5010025

Offor, I., Ehiri, R. and Njoku, C. (2014). Proximate nutritional analysis and heavy metal composition of dried Moringa oleifera leaves from OshiriOnicha LGA, Ebonyi State, Nigeria. Journal of Environmental Science, Toxicology and Food Technology, 8(1), 57-62. https:// doi.org/10.9790/2402-08115762

Olabode, Z., Akanbi, C.T., Olunlade, B. and Adeola, A.A. (2015). Effects of drying temperature on the nutrients of Moringa (Moringa oleifera) leaves and sensory attributes of dried leaves infusion. Direct Research Journal of Agriculture and Food Science, 3(5), 177-122. https://doi.org/10.1155/2020/5376280

Oluduro, A.O. (2012). Evaluation of antimicrobial properties and nutritional potentials of Moringa oleifera Lam. leaf in South-Western Nigeria. Malaysian Journal of Microbiology, 8(2), 59-67. https://doi.org/10.21161/mjm.02912

Oyeyinka, A.T. and Oyeyinka, S.A. (2018). Moringa oleifera as a food fortificant: Recent trends and prospects. Journal of the Saudi Society of Agricultural Sciences, 17(2), 127-136. https:// doi.org/10.1016/j.jssas.2016.02.002

Potisate, Y. and Phoungchandang, S. (2015). Microwave drying of Moringa oleifera (Lam.) leaves: drying characteristics and quality aspects. Asia-Pacific Journal of Science and Technology, 20(1), 12-25. https://doi.org/10.14456/kkurj.2015.2

Rajput, H., Prasad, S., Srivastav, P., Singh, N., Suraj, L. and Chandra, R. (2017). Chemical and Phytochemical Properties of Fresh and Dried Moringa oleifera (PKM-1) Leaf Powder. Chemical Science Review and Letters, 6(22), 1004-1009.

Ranganna, S. (1986). Handbook of analysis and quality control for fruit and vegetable products. New York, USA: Tata McGraw-Hill Education.

Ravichandran, R. and Parthiban, R. (2000). Lipid occurrence, distribution and degradation to flavour volatiles during tea processing. Food Chemistry, 68 (1), 7-13. https://doi.org/10.1016/S0308-8146(99) $00143-0$

Sanni, L., Adebowale, A. and Tafa, S. (2006). Proximate, functional, pasting and sensory qualities of instant yam flour, presented at the 14 ISTRC 
Symposium. Trivandrum, Kerala State, India:

Central Tuber Crops the Research Institute

Sejali, S. and Anuar, M. (2011). Effect of drying methods on phenolic contents of neem (Azadirachta indica) leaf powder. Journal of Herbs, Spices and Medicinal Plants, 17(2), 119-131. https:// doi.org/10.1080/10496475.2011.584293

Sengev, A.I., Abu, J.O. and Gernah, D.I. (2013). Effect of Moringa oleifera leaf powder supplementation on some quality characteristics of wheat bread. Food and Nutrition Sciences, 4(3), 270. https:// doi.org/10.4236/fns.2013.43036.

Shin, L.E.R., Zzaman, W. and Bhat, R. (2015). Influence of dehydration techniques on physicochemical, antioxidant and microbial qualities of Ipomoea aquatica forsk., an underutilized green leafy vegetable. Journal of Food Processing and Preservation, 39(6), 1118-1124. https:// doi.org/10.1111/jfpp.12326

Singh, Y. and Prasad, K. (2013). Moringa oleifera leaf as functional food powder: Characterization and uses. International Journal of Agriculture and Food Science Technology, 4(4), 317-324.

Subadra, S., Monica, J. and Dhabhai, D. (1997). Retention and storage stability of beta-carotene in dehydrated drumstick leaves (Moringa oleifera). International Journal of Food Sciences and Nutrition, 48(6), 373-379. https:// doi.org/10.3109/09637489709028585

Zzaman, W., Silvia, D., Abdullah, W.N.W. and Yang, T.A. (2014). Physicochemical and Quality Characteristics of Cold and Hot Press of Nigella sativa L Seed Oil Using Screw Press. Journal of Applied Sciences Research, 10(12), 36-45. 